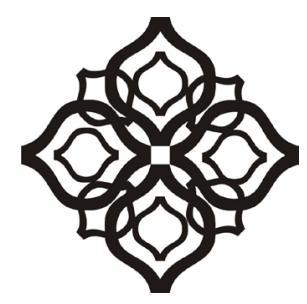

Shirkah

Journal of Economics and Business 


\section{Shirkah}

Journal of Economics and Business

Vol. 3, No. 2, May-August 2018

ISSN: 2503-4235 (p); 2503-4243 (e)

\section{Editor in Chief}

Dwi Condro Triono

\section{Managing Editor}

Jasanta Peranginangin

\section{Editorial Boards}

Abdul Azim Islahi,

Islamic Economics Institute, King Abdulaziz University, Saudi Arabia

Abu Umar Faruq Ahmad,

UBD School of Business and Economics Universiti, Brunei Darussalam

Cedomir Nestorovic,

ESSEC Business School Asia Pacific, Singapore

Fitri Wulandari,

Faculty of Islamic Economics and Business, IAIN Surakarta, Indonesia

Johan Fischer,

Department of Social Sciences and Business Roskilde Universitetscenter, Denmark Muhamed Zulkhibri,

Islamic Research and Training Institute, Islamic Development Bank, Saudi Arabia M. Kabir Hassan,

Department of Economics and Finance, University of New Orleans, United States Musa Asy'arie,

Faculty of Islamic Economics and Business, IAIN Surakarta, Indonesia Nunung Nurul Hidayah,

Aston Business School, Aston University, Birmingham, United Kingdom

Saim Kayadibi,

Department of Economics, Kulliyyah of Economics and Management Science, International Islamic University Malaysia, Malaysia 
Shaikh M Ghazanfar,

Departement of Economics, University of Idaho, Russian Federation

Sigit S. Wibowo,

Department of Management, Faculty of Economics and Business, Universitas Indonesia, Indonesia

Vihang R. Errunza,

Desmarais Global Finance Research Centre, Desautels Faculty and Management, McGill University, Canada

\section{Assistant to Editor}

M. Endy Saputro

M. Zainal Anwar

Shirkah Journal of Economics and Business is a peer-reviewed journal published three times a year (January-April, May-August and September-December) by Faculty of Islamic Economics and Business, Institut Agama Islam Negeri (IAIN) Surakarta Central Java, Indonesia. The main objective of Shirkah is to offer an academic space of exchange ideas and initiate the increase number of qualified article produced by postgraduate students, practitioners and academicians.

\section{Editorial Office}

Ruang Jurnal Shirkah

Lantai Dasar, Sayap Barat, Fakultas Ekonomi dan Bisnis Islam, IAIN Surakarta

Jln. Pandawa No. 1, Kartasura, Sukoharjo, Jawa Tengah Kode Pos. 57168

Phone (+62271) 781516 Fax: (+62271)782336

E-mail: shirkahjournal@iainsurakarta.ac.id; shirkahiainsurakarta@gmail.com Website: http://shirkah.or.id/ 


\section{Shirkah}

\section{Journal of Economics and Business}

Vol. 3, No. 2, May-August 2018

ISSN: 2503-4235 (p); 2503-4243 (e)

\section{Table of Contents}

\section{Articles}

Eko Fajar Cabyono

Lina Nugraha Rani

Macroprudential Policy on Sharia Banking Financing

The Indonesian Experience

Yulianti

Seeing a Buddhist Doing Business in Contemporary Indonesia An Interview with Mr. Sudhamek A.W.S

Fransisca Dwijayanti

Making Economics of Piety

Fashion, Lifestyle and Identity in Pop-Islamism Turn

Indah Piliyanti

Fintech Achieving Sustainable Development

The Side Perspective of Crowdfunding Platform

Taufik Nugroho

Aam S. Rusydiana

Macroeconomic Variables on Indonesian Sharia Capital Market

Hurdle Rate and Adverse Selection on Escalation of Commitment 


\title{
Hurdle Rate and Adverse Selection on Escalation of Commitment
}

\author{
M. Arsyadi Ridha \\ Faculty of Islamic Economics and Business \\ m.ridha@uin-suka.ac.id
}

\begin{abstract}
This article tests the effect of hurdle rates and adverse selection on escalation of commitment. Participants consist of 135 junior managers who had passed two course of management. The result indicates that the managers with adverse selection conditions will tend not to continue unfavorable projects. This research also affirms that the managers with adverse selection conditions will be more likely not to continue projects that are not favorable under the conditions of self-set hurdle rates compared to the conditions of organization-set hurdle rates. This article may contribute to empirical evidence of a decline in comprehensive escalation of commitments.
\end{abstract}

Keyword: adverse selection, self-set hurdle rates, organization-set hurdle rates, escalation of commitment

\section{Introduction}

Such empirical evidences show that project managers tend to endure unfavorable projects (Rutledge \& Karim, 1999; Dewi \& Supriyadi, 2012). This irrational behavior is called escalation of commitment caused by perceptual bias, assessment bias, management impression, and irrational competition from decision makers (Bazerman, 1994). Bounded rationality and unexpected experience of past losses should not be taken into account in decision making by managers (Bazerman, 1994; Fersi \& Boujelbéne, 2017). Manager's escalation behavior may be explained by several theories 
such as self-justification theory (Kutan, Naz, \& Shah, 2018; Brockner, 1992; Beeler \& Hunton, 1997; Cheng, et al, 2003), agency theory (Harrison \& Harrell, 1993; Dewi \& Supriyadi, 2012), and prospect theory (Chepurenko, 2015; White, 1986). The increasing escalation of manager's commitment brings losses to the company. Therefore, a method is badly needed to reduce the escalation of commitment (Gosh, 1997; McNamara, Moon, \& Bromiley, 2002; Cheng, et al, 2003; Chong \& Suryawati, 2010).

A salient issue of the company world would be a question of how to reduce the manager's commitment escalation. Some managers who tend to escalate commitments are those who have a good reputation on some previous projects. If the manager finds a loss at several stages before the project ends, the manager has so high confident that the project will succeed in the end. The manager only thinks of future profits without considering the costs that have been incurred in greater effects. Therefore, reducing the escalation of manager's commitment can be possible in the presence of hurdle rates as a limitation of the ability to continue a project or not. Cheng, et al, (2003) shows that hurdle rates are an effective way of reducing the escalation of commitment managers for non-economic projects, although a more effective self-set hurdle rate reduces commitment escalation rather than an organization-set hurdle rate. Dewi and Supriyadi (2012) show that managers with adverse selection conditions tend to escalate commitments even though the company has conducted monitoring control.

Some other studies shows that hurdle rates can reduce escalation of commitment (Cheng, et al, 2003) and adverse selection can increase the escalation of commitment (Harrison \& Harrell, 1993; Harrell \& Harrison, 1994; Dewi \& Supriyadi, 2012). This raises a gap if the hurdle rates (self-set and organization-set) and the adverse selection are used to show the tendency of escalation of the manager's commitment. The manager's tendency to be in adverse selection conditions (private 
information and incentive to shirk) with the presence of a hurdle rate (selfset and organization-set) to continue or not an unfavorable project. This article aims to examine the effect of hurdle rates and adverse selection on the escalation of manager commitment by using experimental methods. This research contributes to confirm empirical evidence for the decline in comprehensive escalation of commitments.

\section{Developing Hypotheses}

Self-justification theory has been a relevant theory to explain the escalation of commitment at the level of individual decision makers (Brockner, 1992; Cheng, et al, 2003). Individual behaviors who seek to rationalize their previous behavior tend to defend themselves against adverse consequences (Festinger, 1957; Sumaedi, Juniarti, \& Bakti, 2015; Hensel \& Visser, 2018) demonstrates that a person is highly committed when a program is chosen by them and they are personally responsible for the negative consequences. Self-justification theory has been generated from cognitive dissonance theory (Festinger, 1957) and psychological commitment theory (Kiesler, 1971) which explains the motivations underlying the escalation of manager's commitment (Cheng, et al, 2003). Self-justification theory assumes that individuals can surpass the consequences of adverse passive distortions in an attempt to rationalize behavioral error (Dewi \& Supriyadi, 2012). A manager will escalate commitments if they receive information that does not interfere with the decisions they have made on a project. Even though the project losses, they have high trust that the project will succeed in the near future.

Escalation of commitment is an action that refers to irrational decisions to allocate additional resources of a project that has experienced setbacks or losses and prospects for unfavorable future returns (Brockner, 1992; Fox \& Hoffman, 2002). Basically, an individual faces a situation 
where costs have been spent to achieve a goal that is impossible to achieve, regardless of the consequences in the future for the actions that have been taken (Fox \& Hoffman, 2002; Carneiro-Da-Cunha, Dos Santos, De Souza, Alssabak, \& Macau, 2015). Escalation of commitment to a project can occur when there is sustained commitment and negative information (Keil, 1995). Escalation involves commitment of resources in the face of negative interim results, but the end result may be positive or probably negative (Pan, et al, 2006). Allocation of previous resource to the project causes continuous project to fail, although from a rational point of view, past costs are no longer relevant in making decisions (Fox \& Hoffman, 2002).

Capital budgeting or investment valuation can be said to be one of the most important and challenging management tasks in business organizations. One approach of this practice is that companies set hurdle rates or minimum rate of return; the investment projects are required to match funds received by managers (Dutta \& Fan, 2009). Hurdle rates are defined as the expected rate of return from long-term investment opportunities (Kalyebara \& Ahmed, 2011)which are equal to the actual cost of capital (Brealey \& Mysers, 2000). Some agree that the hurdle rate should be based on the cost of capital of an investment (Septyanto, Sudarwan, \& Dewanto, 2017). If the expected rate of return meets a positive function of risk, the company tends to over invest in risk projects (Mahdi \& Abbes, 2018; Abedifar, Molyneux, \& Tarazi, 2013; Ayoub, 2014).

Cheng et al (2003) divided the hurdle rates into two, namely selfset hurdle rates and organization-set hurdle rates. This level of limitation is a limitation for the manager to continue or not continue an unfavorable project. The presence of self-set hurdle rates and organization-set hurdle rates encourage managers to reduce the escalation of their commitments 
because they have limited their ability to a project. Therefore, hypothesis 1 (one) and hypothesis 2 (two) are managers with self-set hurdle rates will be greater not to continue projects that are not profitable than managers who do not have hurdle rates $(\mathrm{H} 1)$ and managers with organization-set hurdle rates will be greater not to continue projects that are not profitable than managers who do not have hurdle rates $(\mathrm{H} 2)$. Managers should invest the resources available in projects that are projected to provide the greatest benefits to the company and periodically evaluate the economic performance of the project. Managers should continue projects that are projected to benefit the company and stop projected projects that are not profitable to avoid corporate losses (Horngren, et al, 2009).

The adverse selection problem arises when managers have private information (for example, information about projections of future project performance) and incentive to shirk or act in their own interests at the expense of principal interests (Chong \& Suryawati, 2010). When these two conditions exist, agent can look irrational from the principal's point of view (such as continuing an unfavorable project) but rational according to the agent (Harrison \& Harrell, 1993). The reason of this seemingly irrational behavior is that managers try to justify their past behavior (Lanfranchi, Giannetto, \& Pascale, 2016; Naz, Shah, \& Kutan, 2017). The irrational behavior of managers who justify their behavior at the expense of perennial interests can harm the company as a whole. Therefore, hypothesis 3 (three) is managers with adverse selection conditions will be more likely to continue projects that are not profitable than managers who are not in that condition $(\mathrm{H} 3)$.

Dewi and Supriyadi (2012) show that managers with adverse selection conditions will tend to continue unfavorable projects. They conducted an interaction between adverse selection and monitoring control in reducing the escalation of commitment but the results did not 
show the expected results. Cheng et al (2003) show that hurdle rates can reduce manager's commitment escalation. They tested hurdle rates with self-set hurdle rates and organization-set hurdle rates while the impact significantly affected the manager's commitment escalation (Moulton, Thomas, \& Pruett, 1996). Self-set hurdle rates predominantly take effect the escalation of manager's commitment rather than organization-set hurdle rates (Hodgkinson \& Starbuck, 2009). Therefore, this article wants to examine the interaction between the adverse selection and hurdle rates (self-set hurdle rates or organization-set hurdle rates) so that the hypothesis 4 (four) and hypothesis 5 (five), and hypothesis 6 (six) are managers with adverse selection conditions will tend to lower projects that are not profitable when there are self-set hurdle rates compared to managers who do not have them (H4); managers with adverse selection conditions will tend to lower projects that are not profitable when there are organization-set hurdle rates compared to managers who do not have them (H5); managers with adverse selection conditions will tend to lower projects that are not profitable when there are self-set hurdle rates compared to managers with organization-set hurdle rates (H6).

\section{Research Design}

This article employs a laboratory experimental procedure with a design of $2 \times 3$ between subjects. The experiment was designed with two independent variables, namely adverse selection and hurdle rates. Adverse selection variables have two levels, namely existing and not adverse selection. Variable hurdle rates have three levels, namely no hurdle rates, self-set hurdle rates, and organization-set hurdle rates. Participants will be placed in one cell from six cells randomly. 
Table 1. 2x3 Experimental Design Between Subject

\begin{tabular}{|l|l|l|l|l|}
\hline \multirow{2}{*}{ Condition } & \multicolumn{3}{|l|}{ Hurdle Rates } \\
\cline { 3 - 5 } & There is no & Self-Set & Organization-set \\
\hline \multirow{2}{*}{ Adverse Selection } & There is no & $\mathbf{K 1}$ & $\mathbf{K} \mathbf{2}$ & $\mathbf{K 3}$ \\
\cline { 2 - 5 } & There is & $\mathbf{K} 4$ & $\mathbf{K} 5$ & $\mathbf{K} 6$ \\
\hline
\end{tabular}

This article uses a real experimental method by adopting the research instruments used by Rutledge \& Karim (1999) and Cheng et al (2003) and adapted to the Indonesian context. The experimental task is divided into two stages. In the first stage, subjects with self-set hurdle rates were given a minimum rate of IRR (internal rate of return) to be a consideration for ending the project. The second stage, all participants were given an explanation that four years ago participants had invested in a project worth Rp100 billion with an estimated economic life of seven years (Yunita, Soraya, \& Maryudi, 2018; Clinton, 1999). Participants were informed that the actual results for the first four years of the project were better than expected (the expected IRR of the first four years was $26.71 \%$ and the actual IRR was 33\%). After a four-year project, unexpected events occur, so the IRR is only $8 \%$ for the next three years. In current conditions, participants are faced with a choice of decision between continuing or not continuing the project. If the project is not continued, funds from the rest of the project can be used for other investment alternatives with an IRR of $17 \%$. The minimum IRR required by the company to continue the project is $15 \%$.

Two groups of participants in the treatment of self-set hurdle rates and organization-set hurdle rates were each given information that (1) information about failure to continue the project was not available to other people in the company or industry (private information), and (2) termination the project will cause other people in companies and 
industries to believe the project failed and downgrade their reputation as highly talented managers and might cause a competing company to attract more important position bids with higher salaries (incentive to shirk). After receiving the information, the participants are asked to make a decision to continue or not continue the existing project with a ten-point Likert scale ( 1 = must continue up to $10=$ definitely not continuing).

After participants make a decision, they answer the question on the questionnaire which is a manipulation check. Manipulation checks are conducted to find out whether participants understand the situation faced when making a project decision. Check manipulation done as in the study of Cheng et al (2003). The questionnaire consists of two components, namely the first component contains two manipulation questions and the second component asks demographics. The first component of the first question asks the subject to indicate the type of hurdle rate (if any) that affects them in making a decision (Dutta \& Fan, 2009). Second questions in the self-set hurdle rates, organization-set hurdle rates, self-set hurdle rates and adverse selection, and organization-set hurdle rates and adverse selection were asked to rate the importance of hurdle rates in reaching their decisions on a ten-point scale (Kalyebara \& Ahmed, 2011). The second component asks a series of demographic questions such as age, gender, and work experience.

The participants belong to those who have passed management accounting and financial management courses. The participants with these criteria are chosen because they already have the ability to assess a project. The participants have also been applied to previous studies (Harrison \& Harrell, 1993; Rutledge \& Karim, 1999; Cheng, et al, 2003; Chong \& Suryawati, 2010; Dewi \& Supriyadi, 2012). The independent variables in this article are 2 (two), namely: adverse selection which is a condition where the manager has private information and incentive to shirk and 
hurdle rates (self-set, organization-set), refers to the manager's level limit for escalating (Zeineb \& Mensi, 2018). The dependent variable is the tendency of managers to escalate commitments to manager's decision preferences to continue (or not) unfavorable projects (Denison, 2009). The hypotheses was tested using ANOVA analysis (analysis of variance) to compare the effect of adverse selection conditions, the existence of a selfset hurdle rate and organization of hurdle rates or not, and whether or not adverse selection and hurdle levels existed rates.

\section{Discussing the Results}

The participants were 150 people, yet not all participants could be used in further testing. They who can be used in testing hypotheses as many as 135 participants because 15 participants did not complete all research procedures and did not pass the manipulation check are shown in table 2. Participant demographic characteristics can be seen in table 3. The results of descriptive statistics show that all participants have passed management accounting courses and financial management. These results indicate that participants are the right proxy for managers. The participants can be used as a substitute for managers (Clinton, 1999).

\section{Table 2. Participant Data}

\begin{tabular}{lll}
\hline \multicolumn{1}{c}{ Information } & \multicolumn{1}{c}{ Amount (people) } & \multicolumn{1}{c}{ Percentage (\%) } \\
\hline $\begin{array}{l}\text { Experimental participant } \\
\begin{array}{l}\text { Participants who did not complete } 4 \\
\text { all research procedures }\end{array}\end{array}$ & $100,00 \%$ \\
$\begin{array}{l}\text { Participants who did not pass the } 11 \\
\text { manipulation check }\end{array}$ & $7,33 \%$ \\
$\begin{array}{l}\text { Participants who were the subjects of } 135 \\
\text { the experiment }\end{array}$ & $90,00 \%$ \\
\hline
\end{tabular}


Table 3. Demographic Characteristics of Participants

\begin{tabular}{|c|c|c|c|}
\hline \multicolumn{2}{|c|}{ Information } & $\begin{array}{l}\text { Amount } \\
\text { (people) }\end{array}$ & $\begin{array}{c}\text { Percentage } \\
(\%)\end{array}$ \\
\hline \multirow[t]{3}{*}{ Gender } & Man & 73 & $54,07 \%$ \\
\hline & Female & 62 & $45,93 \%$ \\
\hline & & 135 & $100,00 \%$ \\
\hline \multirow[t]{4}{*}{ Age } & $18-20$ years old & 34 & $25,19 \%$ \\
\hline & $21-23$ years old & 95 & $70,37 \%$ \\
\hline & $24-26$ years old & 6 & $4,44 \%$ \\
\hline & & 135 & $100,00 \%$ \\
\hline \multirow[t]{3}{*}{ Work experience } & 0 years old & 129 & $95,56 \%$ \\
\hline & $1-3$ years old & 6 & $4,44 \%$ \\
\hline & & 135 & $100,00 \%$ \\
\hline \multirow{3}{*}{$\begin{array}{l}\text { Already taken } \\
\text { management accounting } \\
\text { and financial management } \\
\text { courses }\end{array}$} & Yes & 135 & $100,00 \%$ \\
\hline & No & 0 & $0,00 \%$ \\
\hline & & 135 & $100,00 \%$ \\
\hline
\end{tabular}

Testing experimental data brings the Anova statistics analysis tool. The assumption that must be fulfilled in Anova testing is the data that must have the same variance. This assumption can be shown in the Leven's Test of Equality of Error Variance test in table 4. Based on the results of this test, the $\mathrm{F}$ value is 1.667 with a significance of 0.147 that the Anova model has the same variance.

Table 4. Leven's Test of Equality of Error Variance

\begin{tabular}{llll}
\hline $\mathrm{F}$ & $\mathrm{df1}$ & $\mathrm{df2}$ & Sig. \\
\hline 1,667 & 5 & 129 & 0,147 \\
\hline
\end{tabular}

The results of testing one hypothesis up to the third hypothesis $(\mathrm{H} 1-\mathrm{H} 3)$ are shown in table 5 . Table 5 shows that the hurdle rate has an 
F value of 43.755 with a significance of 0,000 . The hurdle rate has an effect on decreasing the escalation of manager's commitment. Decreasing escalation of commitment is influenced by both the self set hurdle rate and the hurdle rate organization. Based on these tests indicate that $\mathrm{H} 1$ and $\mathrm{H} 2$ are approved.

Table 5. Between-Subject Test Results

\begin{tabular}{llllll}
\hline \multicolumn{1}{c}{ Source } & $\begin{array}{c}\text { Type III Sum } \\
\text { of Squares }\end{array}$ & df & Mean Square & F & Sig. \\
\hline Corrected Model & $500,379^{\mathrm{a}}$ & 5 & 100,076 & 41,695 & 0,000 \\
Intercept & 3439,188 & 1 & 3439,188 & 1432,896 & 0,000 \\
Adverse selection & 59,785 & 1 & 59,785 & 24,909 & 0,000 \\
Hurdle Rates & 210,039 & 2 & 105,020 & 43,755 & 0,000 \\
Adverse selection & 77,826 & 2 & 38,913 & 16,213 & 0,000 \\
$*$ Hurdle Rates & 309,621 & 129 & 2,400 & & \\
Error & 5145,000 & 135 & & & \\
Total & 810,000 & 134 & & & \\
Corrected Total & & & & & \\
\hline
\end{tabular}

a. R Squared $=.618$ (Adjusted R Squared $=.603$ )

The test shows significant support for the third hypothesis (H3) with an $\mathrm{F}$ value of 24,909 with a significance of 0,000. This indicates that the $\mathrm{H} 3$ is supported. Managers with adverse selection conditions will be more likely to continue projects that are not profitable than managers who are not in that condition (Shahari, Zakaria, \& Rahman, 2015). The results of the interaction between the hurdle rates and the adverse selection show significant support under a statistical value of $F$ of 16,213 with a significance of 0,000 . This shows an interaction between hurdle rates and adverse selection. The test results in table 5 cannot show the results of the H4-H6 hypothesis so that the Post Hoc test is carried out. Testing the effect of inter-experimental interactions can be shown in table 6 with multiple comparison testing. 
Table 6. Multiple Comparisons Testing

\begin{tabular}{|c|c|c|c|c|}
\hline (I) Group & (J) Group & $\begin{array}{c}\text { Mean } \\
\text { Difference } \\
(\mathrm{I}-\mathrm{J})\end{array}$ & $\begin{array}{l}\text { Std. } \\
\text { Error }\end{array}$ & Sig. \\
\hline \multirow{5}{*}{$\begin{array}{l}\text { self set hurdle } \\
\text { rate and adverse } \\
\text { selection }\end{array}$} & $\begin{array}{l}\text { self set hurdle rate and no } \\
\text { adverse selection }\end{array}$ & -.028 & .594 & 1.000 \\
\hline & $\begin{array}{l}\text { organization set hurdle rate } \\
\text { and adverse selection }\end{array}$ & .427 & .404 & .952 \\
\hline & $\begin{array}{l}\text { organization set hurdle rate } \\
\text { and no adverse selection }\end{array}$ & $4.179^{*}$ & .447 & .000 \\
\hline & $\begin{array}{l}\text { no hurdle rate and adverse } \\
\text { selection }\end{array}$ & $3.295^{*}$ & .551 & .000 \\
\hline & $\begin{array}{l}\text { no hurdle rate and no adverse } \\
\text { selection }\end{array}$ & $4.121^{*}$ & .393 & .000 \\
\hline \multirow{5}{*}{$\begin{array}{l}\text { self set hurdle rate } \\
\text { and no adverse } \\
\text { selection }\end{array}$} & $\begin{array}{l}\text { self set hurdle rate and adverse } \\
\text { selection }\end{array}$ & .028 & .594 & 1.000 \\
\hline & $\begin{array}{l}\text { organization set hurdle rate } \\
\text { and adverse selection }\end{array}$ & .455 & .587 & .988 \\
\hline & $\begin{array}{l}\text { organization set hurdle rate } \\
\text { and no adverse selection }\end{array}$ & $4.206^{*}$ & .617 & .000 \\
\hline & $\begin{array}{l}\text { no hurdle rate and adverse } \\
\text { selection }\end{array}$ & $3.323^{*}$ & .696 & .001 \\
\hline & $\begin{array}{l}\text { no hurdle rate and no adverse } \\
\text { selection }\end{array}$ & $4.149^{*}$ & .579 & .000 \\
\hline \multirow{5}{*}{$\begin{array}{l}\text { organization set } \\
\text { hurdle rate and } \\
\text { adverse selection }\end{array}$} & $\begin{array}{l}\text { self set hurdle rate and adverse } \\
\text { selection }\end{array}$ & -.427 & .404 & .952 \\
\hline & $\begin{array}{l}\text { self set hurdle rate and no } \\
\text { adverse selection }\end{array}$ & -.455 & .587 & .988 \\
\hline & $\begin{array}{l}\text { organization set hurdle rate } \\
\text { and no adverse selection }\end{array}$ & $3.751^{*}$ & .438 & .000 \\
\hline & $\begin{array}{l}\text { no hurdle rate and adverse } \\
\text { selection }\end{array}$ & $2.868^{*}$ & .544 & .000 \\
\hline & $\begin{array}{l}\text { no hurdle rate and no adverse } \\
\text { selection }\end{array}$ & $3.694^{*}$ & .382 & .000 \\
\hline \multirow{3}{*}{$\begin{array}{l}\text { organization set } \\
\text { hurdle rate and no } \\
\text { adverse selection }\end{array}$} & $\begin{array}{l}\text { self set hurdle rate and adverse } \\
\text { selection }\end{array}$ & $-4.179^{*}$ & .447 & .000 \\
\hline & $\begin{array}{l}\text { self set hurdle rate and no } \\
\text { adverse selection }\end{array}$ & $-4.206^{*}$ & .617 & .000 \\
\hline & $\begin{array}{l}\text { organization set hurdle rate } \\
\text { and adverse selection }\end{array}$ & $-3.751^{*}$ & .438 & .000 \\
\hline
\end{tabular}




\begin{tabular}{|c|c|c|c|c|}
\hline & $\begin{array}{l}\text { no hurdle rate and adverse } \\
\text { selection }\end{array}$ & -.883 & .577 & .799 \\
\hline & $\begin{array}{l}\text { no hurdle rate and no adverse } \\
\text { selection }\end{array}$ & -.057 & .428 & 1.000 \\
\hline \multirow{5}{*}{$\begin{array}{l}\text { no hurdle rate and } \\
\text { adverse selection }\end{array}$} & $\begin{array}{l}\text { self set hurdle rate and adverse } \\
\text { selection }\end{array}$ & $-3.295^{*}$ & .551 & .000 \\
\hline & $\begin{array}{l}\text { self set hurdle rate and no } \\
\text { adverse selection }\end{array}$ & $-3.323^{*}$ & .696 & .001 \\
\hline & $\begin{array}{l}\text { organization set hurdle rate } \\
\text { and adverse selection }\end{array}$ & $-2.868^{*}$ & .544 & .000 \\
\hline & $\begin{array}{l}\text { organization set hurdle rate } \\
\text { and no adverse selection }\end{array}$ & .883 & .577 & .799 \\
\hline & $\begin{array}{l}\text { no hurdle rate and no adverse } \\
\text { selection }\end{array}$ & .826 & .536 & .794 \\
\hline \multirow{5}{*}{$\begin{array}{l}\text { no hurdle rate } \\
\text { and no adverse } \\
\text { selection }\end{array}$} & $\begin{array}{l}\text { self set hurdle rate and adverse } \\
\text { selection }\end{array}$ & $-4.121^{*}$ & .393 & .000 \\
\hline & $\begin{array}{l}\text { self set hurdle rate and no } \\
\text { adverse selection }\end{array}$ & $-4.149^{*}$ & .579 & .000 \\
\hline & $\begin{array}{l}\text { organization set hurdle rate } \\
\text { and adverse selection }\end{array}$ & $-3.694^{*}$ & .382 & .000 \\
\hline & $\begin{array}{l}\text { organization set hurdle rate } \\
\text { and no adverse selection }\end{array}$ & .057 & .428 & 1.000 \\
\hline & $\begin{array}{l}\text { no hurdle rate and adverse } \\
\text { selection }\end{array}$ & -.826 & .536 & .794 \\
\hline
\end{tabular}

*. The mean difference is significant at the 0.05 level.

Table 6 above shows that $\mathrm{H} 4$ is supported. The fourth hypothesis (H4) is the interaction between self set hurdle rate and adverse selection groups with no hurdle rate and adverse selection. The test shows significant support for the fourth hypothesis (H4) under a significance value of 0,000 and a mean of 3,295. Managers with adverse selection conditions will tend to lower projects that are not profitable when there are self-set hurdle rates compared to managers who do not have them. The fifth hypothesis (H5) is the interaction between groups of organizations set hurdle rate and adverse selection with no hurdle rate and adverse selection. The results show significant support for the fifth hypothesis (H5) with a significance 
value of 0,000 and a mean of 2,868. Managers with adverse selection conditions will tend to lower projects that are not profitable when there are organization-set hurdle rates compared to managers who do not have them.

Hypothesis six (H6) tests whether managers with adverse selection conditions will tend to down grade the projects that are not profitable, while there are self-set hurdle rates compared to managers with organization-set hurdle rates. The test shows significant support for the six hypotheses (H6) with a comparison of the mean interaction between self set hurdle rate and adverse selection with no hurdle rate, adverse selection and organization set of hurdle rates, and adverse selection with no hurdle rate and adverse selection. Table 6 shows that H6 is supported, the interaction between the experimental subjects and the ratio of the two means is 3.295 and 2.868 under a significance of 0.000 . The mean comparison of both shows that managers with adverse selection conditions will tend to be more inclined to continue projects that are not profitable while there are self-set hurdle rates compared to managers with organization-set hurdle rates $(3,295>$ 2,868).

\section{Conclusion}

This article initially examines adverse selection interactions with self-set hurdle rates and organization-set hurdle rates. The statistical testing shows that all hypotheses are approved. The managers with self-set hurdle rates will tend to not continue projects that are not profitable than managers who do not have hurdle rates. The managers who have restrictions on their own abilities regarding conditions that are being experienced from previous experience will be more likely to reduce the escalation of their commitment. In addition, the managers with adverse selection conditions will be more likely to continue projects that are not profitable than 
managers who are not in these conditions. When a manager has personal/ confidential information and acts for his own interests, they will be more inclined to escalate commitments related to unfavourable projects.

Furthermore, the managers with adverse selection conditions will tend to subordinate projects that are not profitable while there are self-set hurdle rates compared to managers who do not have them. This happens because a manager has personal information and personal interests but has past experience regarding unfavourable projects. This condition encourages a manager not to continue a project that is not profitable because it has limitations on his own abilities. The managers with adverse selection conditions will tend to lower projects that are not profitable while there are organization-set hurdle rates compared to managers who do not have them. This can occur if a manager is given limitations on the company's ability to continue projects that do not benefit so that it will reduce the escalation of commitment even though the manager has personal information and personal interests.

The managers with adverse selection conditions will tend to lesser projects that are not profitable when there are self-set hurdle rates compared to managers with organization-set hurdle rates. There are interactions between adverse selection with self-set hurdle rates and organization-set hurdle rates. The managers who have personal information and personal interests will be less willing to escalate commitments by measuring their own abilities rather than restrictions from the organization. This research is an experimental study so that the results are very dependent on the subject of research proxy with students so that it must be more careful in generalizing the results. This article only tested the effect of hurdle rates and adverse selection on the escalation of commitments; it can add other independent variables, especially variables that reduce the escalation of commitment of a manager. 


\section{References}

Abedifar, P., Molyneux, P., \& Tarazi, A. (2013). Risk in islamic banking. Review of Finance, 17(6), 2035-2096. https://doi.org/10.1093/rof/ rfs041.

Ayoub, S. (2014). Derivatives in Islamic Finance: Examining the Market Risk Management Framework. Edinburgh: Edinburgh University Press.

Bazerman, M. (1994). Judgment in Managerial Decision Making (Third Edition). Newyork: John Wiley \& Sons, Inc.

Beeler, J., \& Hunton, J. (1997). The Influence of Compensation Method and Disclosure Level on Information Search Strategy and Escalation of Commitment). Journal of Behavioral Decision Making, 10, 77-91.

Ben Salah Mahdi, I., \& Boujelbene Abbes, M. (2018). Relationship between capital, risk and liquidity: a comparative study between Islamic and conventional banks in MENA region. Research in International Business and Finance, 45, 588-596. https://doi.org/10.1016/j. ribaf.2017.07.113.

Ben Zeineb, G., \& Mensi, S. (2018). Corporate governance, risk and efficiency: evidence from GCC Islamic banks. Managerial Finance, 44(5), 551-569. https://doi.org/10.1108/MF-05-2017-0186.

Brealey, R., \& Mysers, S. (2000). Principles of Corporate Finance. McGrawHill.

Brockner, J. (1992). Escalation of Commitment to a Failing Course of Action: Toward Theoretical Progress. Academy of Management Review, 17(1), 39-62.

Carneiro-Da-Cunha, J. A., Dos Santos, M. G., De Souza, L. J., Alssabak, N. A. M., \& Macau, F. R. (2015). The history of an Islamic entrepreneurship: Achieving exporting-network leadership through religious legitimacy. International Journal of Business and Globalisation, 15(3), 272-293. https://doi.org/10.1504/IJBG.2015.071921. 
Cheng, et al. (2003). The Effect of Hurlde Rates on The Level of Escalation of Commitment in Capital Budgeting. Behavioral Research in Accounting, 15, 63-85.

Chepurenko, A. (2015). Entrepreneurship Theory: New challenges and future prospects. Foresight Russia, 9(2), 44-57. https://doi. org/10.17323/1995-459X.2015.2.44.57.

Chong, V. K., \& Suryawati, R. F. (2010). The effect of job rotation policy in preventing managerial escalation of commitment. International Journal of Accounting, Auditing and Performance Evaluation, 7(3), 176-199. https://doi.org/10.1504/IJAAPE.2011.040833.

Clinton, D. (1999). Antecedent of Budgetary Participation: The Efect of Organizational, situational, and individual factors. Advances in Management Accounting, 8, 45-70.

Denison, C. A. (2009). Real options and escalation of commitment: A behavioral analysis of capital investment decisions. Accounting Review, 84(1), 133-155. https://doi.org/10.2308/accr.2009.84.1.133.

Dewi, R., \& Supriyadi. (2012). The Effectiveness of Monitoring Controls and Individual Moral Reasoning in the De-escalation of Commitments. The Indonesian Journal of Accounting Research, 15(1), $1-20$.

Dutta, S., \& Fan, Q. (2009). Hurdle Rates and Project Development Efforts. Accounting Review, 84, 405-432.

Fersi, M., \& Boujelbéne, M. (2017). Capital structure decisions of microfinance institutions and managerial behavioral biases: A survey and future directions. ACRN Journal of Finance and Risk Perspectives, $6(1), 70-89$.

Fox, S., \& Hoffman, M. (2002). Escalation Behavior as A Specific Case of Goal-Directed Activity: A Persistence Paradigm. Basic and Applied Social Psychology, 24, 273-285.

Gosh, D. (1997). De-escalation Strategies: Some Experimental Evidence. Behavioral Research in Accounting, 9, 88-112. 
Harrell, A., \& Harrison, P. (1994). An Incentive to Shirk, Privately Held Information, and Managers' Project Evaluation Decisions. Accounting, Organizations and Society, 19(7), 569-577.

Harrison, P., \& Harrell, A. (1993). Impact of "Adverse Selection" on Managers' Project Evaluation Decisions. Academy of Management Journal, 36(3), 635-643.

Hensel, R., \& Visser, R. (2018). Shared leadership in entrepreneurial teams: the impact of personality. International Journal of Entrepreneurial Behaviour and Research, 24(6), 1104-1119. https://doi.org/10.1108/ IJEBR-03-2018-0133.

Hodgkinson, G. P., \& Starbuck, W. H. (2009). Organizational Decision Making: Mapping Terrains on Different Planets. In The Oxford Handbook of Organizational Decision Making. https://doi. org/10.1093/oxfordhb/9780199290468.003.0001.

Horngren, et al, C. T. (2009). Cost Accounting: A Managerial Emphasis (Vol. 13/E). Prentice Hall.

Kalyebara, B., \& Ahmed, A. . (2011). Determination and Use of a Hurdle Rate in the capital Budgeting Process: Evidence from Listed Australian Companies. IUP Journal of Applied Finance, 17, 59-76.

Keil, M. (1995). Pulling The Plug: Software Project Management and The Problem of Project Escalation. MIS Quarterly, 19, 421-447.

Kutan, A. M., Naz, I., \& Shah, S. M. A. (2018). Are top managers important for firm performance and idiosyncratic risk? Evidence from sharia vs non-sharia-compliant firms in the UK and Pakistan. World Economy, 41(3), 763-780. https://doi.org/10.1111/twec.12511.

Lanfranchi, M., Giannetto, C., \& DE Pascale, A. (2016). Information asymmetry on rfid system in the Agrifood Sector: A study of consumer behaviour. Quality - Access to Success, 17(151), 73-77.

McNamara, G., Moon, H., \& Bromiley, P. (2002). Banking on Commitmen: Intended and Unintended Consequences of an Organization`s Attempt to Attenuate Escalation of Commitment. 
Academy of Management Journal, 45(2), 443-452.

Moulton, W. N., Thomas, H., \& Pruett, M. (1996). Business failure pathways: Environmental stress and organizational response. Journal of Management, 22(4), 571-595. https://doi.org/10.1016/S01492063(96)90025-2.

Naz, I., Shah, S. M. A., \& Kutan, A. M. (2017). Do managers of sharia-compliant firms have distinctive financial styles? Journal of International Financial Markets, Institutions and Money, 46, 174-187. https://doi.org/10.1016/j.intfin.2016.05.005.

Pan, et al, G. (2006). Escalation and De-Escalation of Commitment: A Commitment Transformation Analysis of an E-Government Project. Information System Journal, 16, 3-21.

Rutledge, R., \& Karim, K. (1999). The Influence of Self-interest and Ethical Considerations on Managers' Evaluation Judgments. Accounting, Organizations and Society, 24, 173-184.

Septyanto, D., Sudarwan, \& Dewanto, I. J. (2017). Model behavior of Sharia investment decision on Muslim investor in Indonesia stock exchange (IDX). International Journal of Economic Research, 14(4), 353-363.

Shahari, F., Zakaria, R. H., \& Rahman, M. S. (2015). Investigation of the expected loss of sharia credit instruments in global Islamic banks. International Journal of Managerial Finance, 11(4), 503-512. https:// doi.org/10.1108/IJMF-12-2014-0196.

Sumaedi, S., Juniarti, R. P., \& Bakti, I. G. M. Y. (2015). Understanding trust \& commitment of individual saving customers in Islamic banking: The role of ego involvement. Journal of Islamic Marketing, 6(3), 406-428. https://doi.org/10.1108/JIMA-06-2013-0045.

Yunita, S. A. W., Soraya, E., \& Maryudi, A. (2018). "We are just cheerleaders": Youth's views on their participation in international forest-related decision-making fora. Forest Policy and Economics, 88, 52-58. https://doi.org/10.1016/j.forpol.2017.12.012. 
282 M. Arsyadi Ridha

Vol. 3 No. 2, May - August 2018 


\section{Shirkah Author Guidelines}

Shirkah currently offers two routes to submit manuscripts. We highly recommend to submit the articles which are made using OJS (Open Journal System). Feel free register as author soon through visiting http:// shirkah.or.id/index.php/home/user/register. The authors may directly send their manuscripts, along with their resume, to shirkahiainsurakarta@ gmail.com. Please prepare your manuscripts, using following guidelines:

1. Manuscript must be written in English. Submitted articles should not have been published or be under review for publication with another journal.

2. Manuscript's length is about $15-20$ pages, typed in one-half spaced on A4-paper size.

3. Manuscript must include an $150-200$ word abstract and keywords.

4. Manuscript must be arranged as follows: Title, Name of Author, E-mail address, Abstract, Keywords, Introduction (including method if any), Discussion, Conclusion, References.

5. Manuscript's titles not more than ten words.

6. Manuscript must be submitted in Microsoft Word or RTF.

7. Arabic words should be transliterated according to the style of International Journal of Middle Eastern Studies.

8. Manuscript references are preferably derived from the up-to-date references.

9. The author's resume should be submitted separately, consisting of at least full name, institutional address, phone number, areas of studies, and recent publications (if any).

10. Shirkab use APA Style 6th edition (2010) as reference format writing. We suggest the use of a reference manager software such as Mendeley, Zotero, and Endnote at templating the citation style. APA Style to be used is as follows: 


\section{Book with single author}

Swann, G. M. Peter. (2014). The Economics of Innovation an Introduction. Cheltenhum \& Northampton: Edward Elgar.

in-text citation: (Swann, 2014)

\section{Articles in reference books}

Alatas, S. F. (2006). Islam and the Science of Economics in Abu Rabi', I.M. The Blackwell Companion to Contemporary Islamic Thought. USA: Willey-Blackwell (pp. 587-606).

in text citation: (Alatas, 2006)

\section{E-Book}

Hackett, Rosalind (2007). "Religous Dimentions of War and Peace: Introduction.” Dalam Gerrie ter Haar dan Yoshio Tsuruoka (Ed.), Religion and Society: An Agenda for the 21st Century (h. 3-6). Retrieved from http:// brill.nl.

in text citation: (Hackett, 2006)

\section{Master's thesis, from a commercial database}

McNieI, D. S. (2006). Meaning through narrative: A personal narrative discussing growing up with an alcoholic mother (Master's thesis). Available from ProQuest Dissertations and Theses database. (UMI No. 1434728)

in text citation: (Mc Niel, 2006)

\section{Doctoral dissertation, from an institutional database}

Adams, R. J. (1973). Building a foundation for evaluation of instruction in higher education and continuing education (Doctoral dissertation). Retrieved from http://www.ohiolink.edu/etd/

in text citation: (Adams, 1973) 


\section{Doctoral dissertation, from the web}

Bruckman, A. (1997). MOOSE Crossing: Construction, community, and learning in a networked virtual world for kids (Doctoral dissertation, Massachusetts Institute of Technology). Retrieved from http:/www-static. cc.gatech.edu/--asb/thesis/

in text citation: (Bruckman, 1997)

\section{Journal article with No DOI}

Bourkhis, K., and Nabi, M. S. (2013). Islamic and conventional banks' soundness during the 2007-2008 financial crisis. Journal Metrics, 22(2), 68-77.

in-text citation: (Bourkhis \& Nabi, 2013).

\section{Journal article with DOI}

Ichwan, M. (2012). The Local Politics Of Orthodoxy: The Majelis Ulama Indonesia in the Post-New Order Banten. Journal Of Indonesian Islam, 6(1), 166-194. doi:http://dx.doi.org/10.15642/JIIS.2012.6.1.166-194

In text citation : (Ichwan, 2012)

\section{Abstract as citation}

Hasan, N. (2012). Islamist Party, Electoral Politics And Da'wah Mobilization Among Youth : The Prosperous Justice Party (PKS) in Indonesia. Journal of Indonesian Islam, 6(1), 17-47. Abstract from http:// jiis.uinsby.ac.id/index.php/jiis/article/view/97

in text citation : (Hasan, 2012)

\section{Mass media article}

Sahal, Akhmad (2014, March 2). Kiai Sahal dan Realisme Fikih.Tempo Magazine, p. 120.

in text citation : (Sahal, 2014) 


\section{Research report}

Fisher, B. S., Cullen, F. T., \& Turner, M. G. (2000). The Sexual Victimization of College Women. Research Report.

in text citation : (Fisher, Cullen, Turner, 2000)

\section{Monograph}

Routray, Bibhu Prasad (2013), National Security Decision-Making in India (RSIS Monograph No. 27). Singapura: Rajaratnam School of International Studies.

in text citation : (Routray, 2013)

\section{Proceeding article}

Sudibyakto, Hizbaron, D.R., \& Jati, R (Ed.) (2009), Proceeding International Seminar Disaster Theory, Research and Policy. International seminar held by Sekolah Pascasarjana, Universitas Gajahmada, Yogyakarta, 8-9 Desember 2009.

in text citation : (sudibyakto and Jati, 2009)

\section{Paper conference/seminar/symposium}

Janutama, Herman Sinung (2011). "Kraton dan Hubungan Antar Agama." Paper presented in Seminar Kraton dan Panatagama held by Center for the Study of Islam and Social Transformation (CISForm), Yogyakarta, 17 November.

in text citation :(Janutama, 2011)

\section{Online article in web}

Shiva, (2006, February). Bioethics: A Third World Issue. Native-web. Diperoleh dari http://www.nativeweb.org/ pages/legal/shiva.html

in text citation : (Shiva, 2006) 


\section{Online research report}

Kessy, S. S. A., \& Urio, F M. (2006). The contribution of microfinance institutions to poverty reduction in Tanzania (Research Report No. 06.3). Retrieved from Research on Poverty Alleviation website: http://www. repoa.or.tz /documents_storage/Publications/Reports/06.3_Kessy_and_ Urio.pcif

in text citation : (kessy and urion, 2006)

\section{Holy book}

Qur an, $2(25)$

In text citation : (Q. al-Baqarah 2:25).

\section{Encyclopaedia}

Graycar, Adam (1992). Social Welfare Policy. Dalam Mary Hawkesworth dan Maurice Kogan (Ed.), Encyclopedia of Government and Politics (Vol. 1). London: Routledge.

in text citation : (Graycar, 1992)

\section{Interview}

Sultan Hamengkubuwono X (interview, 2011, April 19)

in text citation: (Hamengkubuwono, 2011)

\section{Documentary film}

Steijlen, Fridus (2008). A Day in the Life of Indonesia [documentary film, 58 minutes]. Leiden: KITLV Press.

in text citation : (Steijlen, 2008) 
Vol. 3 No. 2, May - August 2018 